\author{
УДК 316.32(477) \\ https://doi.org/10.34142/24130060.2019.17.1.09
}

\title{
МІЖНАРОДНИЙ ДОСВІД ІНФОРМАЦІЙНОЇ БЕЗПЕКИ
}

\author{
К.В. Захаренко \\ Національний педагогічний університет імені М.П. Драгоманова
}

В нашій державі існує иіла низка складних проблем в сфері інформаційної безпеки, щзо потребують нагального $i$ кардинального вирімення. Саме тому, особливої актуальності сьогодні набуває теоретико-методологічне та політологічне дослідження проблем національної інформаційної безпеки в Украӥні, щзо переживає кризовий етап свого розвитку. Для розбудови ефективної системи начіональної інформаційної безпеки необхідне детальне вивчення досвіду провідних країн світу, які здійснюють ефективний інформаційний захист свойх держав і громадян. Сьогодні існують начіональні системи інформачійної безпеки, щуо реально довели свою ефективність та структурнофункиіональну довершеність. Адже успішний розвиток демократично-правової держави та громадянського суспільства можливий лише за умови належного використання інформаційних ресурсів та реалізації такої державної політики, яка б забезпечувала високий рівень начіональної інформачійної безпеки. В сучасному світі вже розроблені основні принципи та інструментальні засоби формування ефективного інформаційного захисту національного безпекового простору. Водночас Украӥні необхідно лише адекватно застосувати закордонний досвід найуспішніших в иьому плані краӥн, коректно трансформуючи його з урахуванням начіональної спечифіки й унікальної ролі України в сучасній геополітиці.

Ключові слова: політика, культура, інформаційний простір, інформаційна безпека, політика інформаційної безпеки.

\section{МЕЖДУНАРОДНЫЙ ОПЫТ ИНФОРМАЦИОННОЙ БЕЗОПАСНОСТИ}

\section{К.В. Захаренко}

В нашем государстве существует иельй ряд сложных проблем в сфере информационной безопасности, что требует неотложного и кардинального решения. Именно поэтому, особенную актуальность сегодня приобретает теоретикометодологическое и политологическое исследование проблем начиональной информационной безопасности в Украине, которая переживает кризисный этап своего развития. Для перестройки эффективной системы национальной информационной безопасности необходимо детальное изучение опыта ведущих стран мира, которые осуществляют эффективную информационную защиту своих государств и граждан. Сегодня существуют начиональные системы информационной безопасности, что реально довели свою эффективность и структурно функииональную совершенство. Ведь успешное развитие демократически правового государства и гражданского общества возможно лишь при условии надлежащего использования информачионных ресурсов и реализачии такой государственной политики, которая бы обеспечивала высокий уровень национальной информачионной безопасности. В современном мире уже разработань основные принципь и инструментальные средства формирования эффрективной информационной защиты национального пространства безопасности. В то же время

(C) К.К. Захаренко, 2019 
Украине необходимо лишь адекватно применить международный опыт самых успешных в этом плане стран, корректно трансформируя его с учетом начиональной специфики и уникальной роли Украины в современной геополитике.

Ключевые слова: политика, культура, информачионное пространство, информаџионная безопасность, политика информаџионной безопасности.

\section{INTERNATIONAL EXPERIENCE OF INFORMATION SECURITY}

\section{K. Zakharenko}

In our state there are a number of complex problems in the field of information security that require urgent and radical solution. That's why theoretical, methodological and political research of the problem of information security in Ukraine, which is experiencing a crisis phase of its development, is becoming especially relevant today. In order to develop an effective system of national information security, a detailed study of the experience of the leading countries of the world, which carry out effective information protection of their states and citizens, is necessary. Today there are national information security systems that have really proven their effectiveness and structural and functional perfection. Indeed, the successful development of a democratic state and civil society is possible only if the information resources are properly used and the state policy is implemented, which would ensure a high level of national information security. In the modern world, the basic principles and tools for the formation of effective information protection of the national security space have been developed already. At the same time, Ukraine needs to apply adequately the foreign experience of the most successful countries in this regard, correctly transforming it taking into account national specificity and the unique role of Ukraine in modern geopolitics.

As an important indicator of the protection of citizens, society and state, information security is an integral part of national security. Therefore, its determination mainly focuses on preventing harmful effects that may result in various information threats, as well as eliminating and overcoming those effects with the least possible harm to society and humans. In this aspect, the study of not only the philosophical and phenomenological and socio-psychological determinants of information security of citizens, but also political and legal resources and mechanisms of protection of the information space of the state in the conditions of the functioning of the global information society acquires a special significance.

A content analysis of the notion «information security» as a form of national security aimed at ensuring human rights and freedoms in relation to free information access, creation and implementation of secure information technologies and protection of the property rights of all participants of information activities, includes consideration of possible diversions in this area, especially at the international level. Today there is a situation of incompleteness of formation and fragmentary filling of the information space content of the country and the legislative base in our society. The efficiency of the information weapon itself has increased too quickly due to the rapid information circulation and the spread of information networks. As a result, mass media forms the «mass» person of our time, in turn this fact displaces traditional direct contacts, by dissociating people and replacing them by computers and television. At the same time it gives rise to apathy, uncritical attitude and indifference, it complicates the adequate orientation, causing the social disorientation.

Informative safety has the human measuring. Therefore an important role in opposition to destructive external and internal informative influences is played by education of citizens. Her proper level called to provide the state and civil society. An in fact uneducated population easily is under destructive influence of informative threats of the modern global world. Unfortunately, Ukraine, does not have sufficient resources and technologies for adequate opposition to the external threats. Taking into account it strategy of forming of the national system of informative safety of our state can be only the maximal leveling of destructive influences from the side of 
external informative threats. To the end it is necessary to carry out democratic reforms Ukraine, generate civil society, to provide functioning of the legal state and increase of political and civil culture of population. At the same time it is necessary to bear reformers in a mind, that global nature of informative society predetermines rapid transformation of external threats in internal, converting them into permanent calls which are opened out within the limits of national in a civilized manner-informative and socio-political space. Besides modern global informative systems, mass medias, network facilities do a limit between external and internal threats almost unnoticeable.

Key words: politics, culture, information space, information security, information security policy.

Постановка проблеми. Інформація стала потужним засобом маніпулювання суспільною та індивідуальною свідомістю, а також реальною зброєю, що використовується в конфліктах нового типу, конфронтаціях та протистояннях. Створення можливостей доступу кожного до джерел інформації, формування уміння користуватись нею й одночасно захист людей від брудних інформаційних потоків створюють своєрідне предметнодослідницьке поле, одним з найбільш актуальних аспектів якого є проблема формування та реалізації політики інформаційної безпеки на державному, суспільному та громадянському рівнях.

Ще одними аспектом актуалізації проблематики інформаційної безпеки $\epsilon$ те, що саме інформація є одним 3 основних інструментів вибудовування архітектури сучасної глобальної цивілізації. Держави-лідери глибоко усвідомлюють, що саме контроль над інформаційними ресурсами і потоками та ефективне використання новітніх інформаційних технологій здатні підтримувати їх лідерство. Це значною мірою актуалізує проблематику інформаційної безпеки і суверенітету окремих держав, що є як суб'єктами, так і об’єктами інформаційних впливів різного характеру.

Аналіз актуальних досліджень. Дослідженню цієї проблематики присвячена досить помітна кількість наукових публікацій та рекомендацій практичних політиків. В західній науковій літературі вагоме слово у цьому контексті висловили такі знамениті дослідники, як Д. Белл, З. Бжезинський, Л. Бриллюен, Л. Войтасек, В. Дайзард, К. Каяма, М. Кастельєс, І. Масуда, Кр. Мей, А. Моль, Дж. Нейсбіт, М. Порат, Т. Стоуньер, О. Тоффлер, Г. Шиллер тощо. 
Мета статті. Не вироблено ефективної моделі системного забезпечення інформаційної безпеки держави, суспільства i людини, хоча така необхідність зафіксована на конституційному рівні. Тому сьогодні дуже важливо розробити цілісний кодифікаційний документ, який повноцінно охопив би різні аспекти формування державної політики в сфері національної безпеки, а також визначив би конкретний інструментарій їі реалізації.

Виклад основного матеріалу. У різних державах розроблені основні принципи та інструментальні засоби формування ефективного інформаційного захисту національного простору. Застосовуючи різні засоби, країни-лідери достатньо ефективно здійснюють національну політику інформаційної безпеки. Україні необхідно вивчити й адекватно застосувати закордонний досвід, трансформуючи його відповідно до національної специфіки й унікальної ролі держави в сучасній геополітиці. В нашій країні наявна низка складних проблем в сфері інформаційної безпеки, що потребують нагального і кардинального вирішення. Водночас їх розв’язання передбачає не тільки концептуально-теоретичне осягнення питань інформаційної безпеки, але й створення такого національного законодавства, яке підводило б нормативно-правове підгрунтя під діяльність різних суб’єктів інформаційного простору. «Найбільш розвинуті системи інформаційної безпеки функціонують у США, Великій Британії, Ізраїлі, ФРН, Російській Федерації, Китаї, тобто у тих країнах, які постійно знаходяться під потужним зовнішнім інформаційним впливом, а тому вимушені створювати національні системи інформаційного захисту. Притому зазначені системи цих країн мають і достатню активну складову, завдяки чому існує можливість проведення інформаційно-психологічних заходів та кібернетичних атак проти країн-супротивників» (Левченко, 2014, с. 168).

Особливою багатою вимірністю та ефективністю система інформаційної безпеки вирізняється у такого глобального геополітичного гравця, як Сполучені Штати Америки. Необхідно відзначити, що система інформаційної безпеки в США є надзвичайно багатомірною і складною, а 
також спирається на достатньо деталізоване, але підпорядковане єдиній стратегії федеральне та місцеве законодавство. «Законодавство США у сфері забезпечення інформаційної безпеки - це сукупність федеральних законів та законів штатів, які створюють правову основу для здійснення державної політики у цій сфері. Досить грунтовно в законодавстві врегульовано питання щодо забезпечення безпеки інформації в державних комп’ютерних системах (Закон «Про комп’ютерну безпеку», Закон «Про удосконалення інформаційної безпеки»), боротьби 3 комп’ютерною злочинністю (Закон «Про комп’ютерне шахрайство та зловживання», Закон «Про зловживання комп’ютерами»), регулювання співвідношення прав громадян на отримання інформації (Закон «Про свободу інформації», Закон «Про висвітлення діяльності уряду») та конфіденційність їх приватного життя (Закон «Про охорону особистих таємниць»). Адміністративно-організаційне забезпечення інформаційної безпеки в США спрямоване на координацію всіх дій по захисту інформації та проведення єдиної державної політики інформаційної безпеки. Президент США $є$ основною відповідальною особою за забезпечення національної безпеки загалом та інформаційної безпеки зокрема» (Конах, 2005, с. 9-10). Зрозуміло, що США як наддержава ставить перед собою зовсім інші цілі, аніж Україна в рамках власної безпекової політики. Ми не можемо розраховувати на ті матеріальні і технологічні ресурси, що використовуються в Сполучених Штатах з метою забезпечення національної та громадської інформаційної безпеки. В той же час, українські спеціалісти можуть сприйняти окремий технологічний досвід, а законодавці мають вивчати ті способи нормативного забезпечення інформаційної політики держави, що зарекомендували себе в США як універсальні та доволі ефективні.

Розвинені країни Свропи також велику увагу приділяють всебічному забезпеченню в рамках національної політики, економіки, безпеки, громадянського суспільства інформаційного захисту від загроз, що постають в сучасному глобальному інформаційному суспільстві. Так, у Франції 
інформаційний сектор функціонування національного суспільства визначається одним з ключових, поряд з економікою, політикою, культурою. Захист інформаційного простору визнається одним 3 ключових i найважливіших напрямів забезпечення національної безпеки Французької Республіки. «Франція вважає, що у низці основних секторів, які потребують державного захисту, поряд 3 енергетикою, транспортом, фінансами $\epsilon$ інформаційна сфери, зокрема системи забезпечення безпеки інформації обмеженого користування, насамперед державної таємниці, та телекомунікаційні служби. Можна зробити висновок, що саме в цьому виявляється новий елемент у понятті сучасної багатовекторності геостратегії французької правлячої еліти, що безпосередньо впливає на особливості вибору способів використання оперативних можливостей національних спецслужб, ЗМІ та інших державних і неурядових структур, залучених до реалізації політики інформаційної безпеки французького суспільства і держави. Як наслідок, національний інформаційний простір Французької Республіки стає основним об’єктом захисту під час формування відповідних завдань, структури механізму та сучасного поняття тактики реалізації його сил і засобів у розвідувально-інформаційних та розвідувально-підривних заходах, зокрема у діяльності спецслужб щодо проведення спеціальних заходів, пов'язаних із захистом французького інформаційного простору від негативних зовнішніх проявів і здійснення вигідних легальних та таємних вигідних впливів на іноземних партнерів і/або опонентів» (Остроухой, та ін. ред., 2010, с. 343-344). Таким чином, інформаційний простір у Франції розглядається як однин з пріоритетних об’єктів спеціального захисту, який здійснюється всіма можливими законотворчими, організаційноуправлінськими, силовими та інформаційно-технологічними засобами. Принагідно французький уряд та громадянське суспільство постійно проводять моніторингові заходи, всіляко запобігаючи можливим спробам 3 боку державних функціонерів обмежувати демократію, виправдовуючись 
необхідність здійснення певних заходів по контролю над національним інформаційним простором.

Менш демократично в цьому питанні поводить себе уряд Китайської Народної Республіки. В інформаційній політиці Китаю домінують принципи втілення достатньо моноцентричних оборонних і наступальних доктрин. В політичному та безпековому дискурсі КНР інформація, як в їі соціальнокультурному, так і в технологічно-інноваційному вимірах, розглядається насамперед як збройний ресурс, як засіб впливу на власних громадян та активного захисту i протидії зовнішнім інформаційним впливам. Використання могутньої та широкої ресурсної бази дозволяє Китаю проводити достатньо ефективну інформаційну політику, навіть незважаючи на ï недемократичну спрямованість. «Політика інформаційної безпеки визначає пріоритетними напрямами діяльності держави розробку національних стратегій, які поєднують оборонні і наступальні доктрини для забезпечення національних інтересів і захисту внутрішнього інформаційного середовища та інформаційної інфраструктури, подолання асиметричності інформаційного розвитку щодо інформаційно розвинених країн як потенційних супротивників в інформаційному протистоянні. Всі структурні складові державної інформаційної політики зумовлені потребою забезпечення національних інтересів шляхом реалізації китайської моделі інформаційного суспільства та специфіки інтеграції КНР у глобальне інформаційне середовище. Включення стратегії державної інформаційної політики в урядові програми дає Китаю можливість реформувати політичну ідеологію в контексті сучасних тенденцій міжнародного розвитку. Участь КНР в процесах міжнародної регіональної інтеграції формує стратегію інформаційної політики держави, яка полягає в одночасній інтеграції до світової системи міжнародних відносин і практичній реалізації національної моделі інформаціоналізму як чинника модернізації політичної системи КНР та іiі потенційного лідерства на регіональному та міжнародному рівнях» (Хуан Цинь, 2007, с. 8-9). Таким чином, можна зазначити успішні спроби 
Китаю в реалізації власної моделі інформаційної політики, яка охоплює як внутрішні проблеми країни, так і іiі регіональні та глобальні геополітичні зазіхання. Багато в чому саме завдяки розробці власної моделі інформаціоналізму КНР поступово досягає успіху, виконуючи завдання по перетворенню на одного 3 ключових гравців на глобальній геополітичній «шахівниці», створюючи значну конкуренцію не тільки Європі, але й Сполученим Штатам Америки.

Таким чином, в світі існують країни з різними традиціями державного управління, які достатньо ефективно здійснюють національну політику інформаційної безпеки, застосовуючи різні засоби: від створення систематизованої нормативно-правової бази до використання значних матеріально-технологічних ресурсів. Вивчаючи успішний досвід країнлідерів, можна залучати певні моменти, що спричинили б позитивний вплив на вирішення багатьох проблем, що існують сьогодні в інформаційнобезпековому полі України. «Політико-правовий аналіз стану управління захистом безпекових інтересів в України свідчить, що його рівень не задовольняє потреби суспільства та держави. Серед чинників, які це спричиняють, необхідно визначити: відсутність організаційної системи розроблення й реалізації єдиної державної політики в галузі забезпечення інформаційно-психологічної безпеки; нерозуміння інформаційнопсихологічної боротьби як механізму протидії експансії та агресії стосовно країни в будь-якій формі ii прояву та забезпечення власних національних інтересів; недостатня розвиненість науково-методичної бази забезпечення інформаційно-психологічної безпеки, стратегії й тактики ведення інформаційно-психологічної боротьби; відсутність підготовки фахівців 3 комплексним баченням проблем інформаційно-психологічної безпеки країни, а також організації та ведення інформаційно-психологічної боротьби. За таких умов держава не спроможна протистояти масованому інформаційнопсихологічному впливу 3 боку інших країн та ефективно виконувати 
завдання інформаційно-психологічної боротьби для забезпечення національних інтересів» (Кирильчук, 2013, с. 11).

Актуальності цій проблематиці надає i те, що перед українською державою і суспільством постійно постають нові виклики, збуджувані як динамічною глобальною ситуацією, що постійно змінюється через бурхливий розвиток інформаційної цивілізації, так агресивною політикою Російської Федерації на регіональному геополітичному рівні. Складаються такі обставини, коли Україна змушена формувати власну систему інформаційної безпеки, не стільки вибудовуючи стратегію, скільки реагуючи на все нові й нові виклики. «За цих обставин перед керівництвом України постає проблема необхідності усвідомлення нового характер викликів та загроз, що стоять перед країною і набувають значних масштабів. Відповідно інтереси України вимагають формування системи, що дозволить їй адекватно реагувати на негативні зовнішні та внутрішні впливи, зберігати цілісність суспільства та держави» (Смола, 2011, с. 3). Для побудови такої системи першочергово необхідно провести значну аналітичну підготовку, на основі якої чітко визначитись із пріоритетами та орієнтирами подальшої державної інформаційної політики. Окрім того, важливо обирати такі засоби інформаційного захисту, які б були достатньо ефективними на даний момент i, при цьому, потребували б адекватних ресурсних та технологічних затрат. Це також вимагає серйозного концептуально-теоретичного пошуку в сфері визначення основних засад державної інформаційно-безпекової політики.

Продовженням концептуально-теоретичних пошуків в галузі інформаційної безпеки має стати створення систематизованого національного законодавства, що підводило б нормативно-правове підгрунтя під діяльність різних суб'єктів, в тому числі й держави, в сфері забезпечення різних рівнів інформаційної безпеки суспільства. Особливо важливо, з нашої точки зору, врахувати при цьому успішний досвід європейських країн, що ефективно захищають свій інформаційний простір від шкідливих зовнішніх впливів. «Назріла нагальна потреба здійснення кодифікації інформаційного 
законодавства України, зокрема шляхом прийняття Інформаційного кодексу України. Існує необхідності врахування під час практичної розробки дієвого Інформаційного кодексу України європейських стандартів у сфері захисту інформації та забезпечення інформаційної безпеки людини, суспільства і держави. Визначено доцільність включення до проекту Інформаційного кодексу норм комп’ютерної етики, морально-етичних основ регулювання взаємовідносин між комп’ютером та людиною в міжнародному мережевому просторі. Увага акцентується на необхідності прийняття такого нормативноправового акта, положеннями якого буде передбачено основні засади інформаційного розвитку держави, врегульовано діяльність органів державної влади України щодо забезпечення інформаційної безпеки (у тому числі протидії інформаційним війнам), визначено ключові принципи забезпечення інформаційної безпеки людини, суспільства, держави та подальшого інформаційного розвитку України, закріплено систему заходів, своєчасне виконання яких сприятиме зміцненню інформаційної безпеки (у тому числі у сфері протидії інформаційним війнам) та виведенню діяльності щодо іiі зміцнення на якісно новий рівень» (Абакумов, 2011, с. 12). Таким чином, кодифікація національного законодавства в галузі інформаційної безпеки може вирішити проблему систематизації даної сфери державної та суспільної життєдіяльності. Важливо лише, щоб така кодифікація відбувалася на основі чітко розроблених та структурно вибудуваних теоретико-методологічних засад дослідження інформаційно-безпекового сегменту діяльності української держави і громадянського суспільства.

Окрім того, теоретична проблематика інформаційної безпеки, що досліджується в рамках сучасного філософсько-політологічного дискурсу, переконливо доводить свою актуальність i в питаннях державного та громадського управління. Саме інформація стає інклюзивним, інтегративним, наскрізним ресурсом, що дозволяє максимально ефективно управляти тією чи іншою спільнотою в рамках сучасної інформаційної цивілізації. «Ефективне управління сучасним інформаційним суспільством має 
обов'язково передбачати формування державної інформаційної політики та створення належних умов іiі реалізації, а метою цієї діяльності повинне стати узгодження системно-функціональної та інформаційної складових в умовах стрімкого поширення процесів глобалізації. Звідси зрозуміло, чому проблема забезпечення інформаційної безпеки увійшла до числа найбільш значущих і пріоритетних завдань, вирішення яких необхідне для існування й подальшого розвитку нашого суспільства. Інформаційна безпека важлива тому, що ми захищаємо свій інформаційний простір, а отже, свої інформаційні ресурси, свою національну культуру. Зрештою, ми захищаємо себе, своє право на життя, своє місце в історії» (Дзьобань, 2011, с. 207). Таким чином, філософська специфіка проблематики інформаційної безпеки полягає в тому, що інформація сьогодні стала ресурсом глобального об'єднання людства, що несе багато нових можливостей, але ставить перед окремими спільнотами $і$ людством в цілому нові виклики і ризики. Від того чи зможемо ми відповісти на ці виклики максимально адекватно, захистивши свій інформаційний простір від багатьох небезпек і шкідливих впливів, багато в чому залежить успіх та своєчасність національно-будівничих та державотворчих зусиль, що здійснюються українським народом в складних геополітичних та глобальноцивілізаційних умовах.

Сьогодні успішний розвиток демократично-правової держави та громадянського суспільства можливий лише за умов повноцінного використання інформаційних ресурсів, а також встановлення чіткої державної політики, що забезпечувала б високий рівень національної інформаційної безпеки. Фактично, інформаційна безпека держави i національного соціуму стає ключовим чинником демократичних перетворень всередині країни, а також іï виходу на конкурентоспроможний рівень в регіональному та глобальному масштабі. «Національна інформаційна безпека України нині постає як одне 3 найважливіших завдань, від успішного розв'язання якого залежить цілісність, суверенітет, суспільний прогрес України. Практичне забезпечення національної інформаційної безпеки 
можливе за рахунок єдності усіх факторів - політичного, економічного, правового, організаційного та ін. Національна інформаційна безпека реальний фактор успішної геостратегічної політики України, водночас 3 демократичним суспільним розвитком українського соціуму» (Кирильчук, 2013, с. 62). Це й зумовлює значний рівень актуальності концептуальнотеоретичних досліджень філософсько-політологічного характеру, спрямованих на вивчення всієї повноти можливостей, які дозволяють сучасним державам і суспільствам захищати свій інформаційний простір від величезної кількості викликів і проблем, що постають в рамках глобальної інформаційної цивілізації. Цим зумовлена й актуальність і важливість визначення теоретико-методологічних засад дослідження інформаційної безпеки, що проводиться в нашому дисертаційному дослідженні.

Висновки і перспективи подальших досліджень. Таким чином, визначившись 3 основними витоками та детермінантами актуальності проблеми інформаційної безпеки, розглянувши різні дискурсивні традиції та способи визначення категорії «інформаційна безпека», що існують в українському та іноземному політологічному дискурсі, а також здійснивши компаративний аналіз відображення проблеми інформаційної безпеки в системі інформаційної політики України та провідних країн світу, можемо зробити низку взаємопов'язаних висновків про основні принципи та теоретико-методологічні засади нашого дослідження поставленої проблематики.

По-перше, визначивши основні витоки та детермінанти проблеми інформаційної безпеки, доведено значну актуальність та багатовимірність концептуально-теоретичного вивчення та аналізу даної проблеми в сучасному філософсько-політологічному та національно-безпековому дискурсі. Насамперед, основною детермінантою актуальності проблематики інформаційної безпеки є значне зростання інформаційних потоків і обмінів на глобальному рівні. Таке зростання ставить перед національними безпековими просторами багато викликів i труднощів, які вимагають 
постійного дослідження i вирішення. Додаткової небезпеки додають інформаційні втручання, що здійснюються на регіональному геополітичному рівні. При цьому інформаційні виклики постають перед усіма: людиною, громадянином, суспільством, народом, державою. Це й створює надзвичайну складність концептуально-теоретичного дослідження проблем інформаційної безпеки. В нашому дослідженні одним 3 основних методів визначено комплексно-системний підхід, на основі якого здійснюється цілісне вивчення проблем інформаційної безпеки, що постають і перед людиною, і перед суспільством, і перед державою. Полісуб'єктність інформаційно-безпекового поля зумовлює складність, важливість i актуальність дослідження поставленої проблематики з точки зору філософсько-світоглядної рефлексії та політологічно-безпекової аналітики.

По-друге, проаналізувавши основні принципи та критерії визначення поняття «інформаційна безпека» суспільства в контексті сучасного філософсько-політологічного дискурсу, підкреслено значну різноманітність та поліваріантність таких визначень. Українські та закордонні дослідники даної проблематики, визначаючи категорію інформаційної безпеки, звертаються до таких іiі аспектів, як глобально-цивілізаційна значимість, роль у забезпеченні національної безпеки і оборони, визначення інформаційнотехнологічних параметрів безпеки, значення забезпечення інформаційної безпеки кожної окремої особистості чи конкретних соціальних спільнот. 3 огляду на таке різноманіття підходів, ключовим теоретико-методологічним принципом нашого дослідження обрано принцип системності, на основі якого робиться комплексний, структурно-функціональний аналіз категорії «інформаційна безпека» 3 урахуванням ii індивідуальних, соціальних, державних і глобальних вимірів. При такому розгляді особливо важливо формулювати інтегративні чинники, що поєднують інформаційну безпеку держави і суспільства 3 інформаційно-психологічною та світогляднофеноменологічною безпекою кожної людини. 3 огляду на такі теоретикометодологічні засади дослідження проблеми інформаційної безпеки, ми 
визначаємо дане поняття як вид національної безпеки, спрямований на забезпечення прав і свобод людини щодо вільного доступу до інформації, створення і впровадження безпечних інформаційних технологій та захист прав власності всіх учасників інформаційної діяльності.

По-третє, здійснивши компаративний огляд відображення проблеми інформаційної безпеки в системі інформаційної політики України та провідних країн світу, доведено необхідність розробки систематизованої стратегії формування інформаційно-безпекової політики в нашій державі. На сьогодні в нашій державі ще не сформовано відповідної сучасним цивілізаційним та геополітичним викликам системи інформаційної безпеки. Існує необхідність посилення буквально на всіх напрямах: нормативноправовому, організаційно-управлінському, інформаційно-технологічному. Але насамперед існує нагальна необхідність вироблення чіткої стратегії здійснення перетворень в секторі інформаційної безпеки держави i національного суспільства. Така стратегія має грунтуватися на міцному концептуально-теоретичному, науково-практичному базисі, який має сформуватися в рамках національного політологічного дискурсу. Саме тому дослідження багатоаспектної проблематики інформаційної безпеки держави, соціуму і людини є сьогодні надзвичайно актуальним і важливим завданням, що постає перед науковою спільнотою нашої країни.

\section{ЛІТЕРАТУРА}

1. Абакумов, В.М., 2011. Правове регулювання протидї інформаційним війнам в Україні. Кандидат наук. Автореферат. Класичний приватний університет, Запоріжжя.

2. Дзьобань, О.П. 2011. Інформачійне насильство та безпека: світоглядно-правові аспекти: монографія. Харків: Майдан.

3. Остроухой, Б.В., Петрик, Б.М., Присяжнюк, М.М. та ін. ред., 2010. Інформаціна безпека (сочіально-правові аспекти): підручник. Київ.

4. Кирильчук, Є.О., 2013. Проблеми національної інформаційної безпеки України в контексті сучасних національних державотворчих процесів та світової інтеграції. Наукові пращі МАУП, 1(36), с. 60-63.

5. Коваль, 3.В., 2011. Політико-правові механізми державного управління інформаційно-психологічною безпекою Украӥни. Кандидат наук. Автореферат. Одеський регіональний інститут державного управління Національної академії державного управління при Президентові України. 
6. Конах, В.К., 2005. Забезпечення інформаційної безпеки держави як складової системи національної безпеки (приклад США). Кандидат наук. Автореферат. Національний інститут стратегічних досліджень, Київ.

7. Левченко, О.В., 2014. Проблеми і шляхи формування системи інформаційної безпеки держави. Збірник наукових пращь Харківського університету Повітряних Сил, 2(39), c. $166-168$.

8. Смола, Л.Є., 2011. Інформачійно-психологічні детермінанти сучасного політичного процесу (світовий та вітчизняний контексти). Доктор наук. Автореферат. Львівський національний університет імені Івана Франка.

9. Хуан Цинь, 2007. Інформаційна політика Китайської Народної Республіки в сучасних міжнародних відносинах. Кандидат наук. Автореферат. Київський національний університет імені Тараса Шевченка.

\section{Інформація про автора}

Захаренко Костянтин Володимирович - кандидат політичних наук, доцент, доцент кафедри політичної психології та соціально-правових технологій Національний педагогічний університет імені М.П. Драгоманова; e-mail: kzakharenko@ukr.net; ORCID: http://orcid.org/0000-0003-0980-7313.

Стаття надійшла до редакції: 28.01.2019 р. Прийнята до друку: 08.02.2019 p. 